\title{
LAJIKKEEN, KORJUUAJAN JA -MENETELMÄN VAIKUTUS KEVÄTVEHNÄN ITÄVYYTEEN JA ITÄMISKYPSYMÄTTÖMYYTEEN
}

\author{
Ulla LallukKa \\ Helsingin yliopiston kasvinviljelytieteen laitos
}

Saapunut 21. 4. 1971

THE EFFECT OF HARVESTING TIME AND HARVESTING METHOD UPON THE
GERMINATION AND DORMANCY OF SPRING WHEAT CULTIVARS

Ulla Lallukka

Department of Plant Husbandry, University of Helsinki

\begin{abstract}
A study was made of the effects of cultivar, harvesting time and harvesting method upon the germinability and the dormancy of spring wheat. It was found that in respect of germinability the spring wheat met the requirements generally placed on good seed provided that the crop was cut at the milk-ripening to full-ripening stage and that the procedure permitted after-ripening before threshing. The germinability of grain harvested at milk-ripeness was very low when the harvesting method did not include after-ripening. There was some decrease in germinability with delay in harvesting.

Of the cultivars investigated, Norröna and Svenno seemed most poorly to withstand threshing at the early stage of ripening. When harvested at an over-ripeness stage, the germinability of Norröna declined most sharply.

The dormancy of the grain $2-3$ weeks after harvesting appeared to be greater in the treatments harvested early than in the treatments harvested at full-ripeness or overripeness stages, especially when the harvesting method did not involve after-ripening. Dormancy was greater in the cultivars resistant to sprouting in the ear than in the cultivars susceptible to it. The weather conditions that preceded ripeness also seemed to affect the dormancy of the seed.

By sowing time, however, dormancy had declined to such an extent that the germinability of the wheat met the requirements placed on seed.
\end{abstract}

Vehnän korjuuajankohtaa koskevissa tutkimuksissa on viime vuosina huomio kiinnitetty pääasiassa leipäviljaksi tarkoitetun vehnän laadun kohottamiseen. Tämä on luonnollista, koska pääosa vehnäsadosta käytetään leipäviljana. Useina vuosina on meillä todettu riittävän aikaisen leikkuupuinnin olevan korkeatasoisen leipäviljan tuottamisen edellytyksenä (NeUvonen 1966, Köylijärvi 1968, LallukKa 1971).

Kylvösiemeneksi tarkoitetun viljan puintikosteutta koskevissa tutkimuksissa on $25 \%$ :n vesipitoisuus jatkuvasti osoittautunut sopivan puintikosteuden ylärajaksi vehnällä (VALLE 1954, KöYLIJÄRvı 1970). Liian varhaisessa tuleentumisvaiheessa suoritettu leikkuupuinti 
saattaa vaikuttaa siemenviljan laatuun aiheuttamalla puinti-ja kuivatusvaurioiden lisäksi myös itämiskypsymättömyyttä (Suomela 1969).

Viikissä määritettiin vuosina 1966-1968 leipäviljaksi tarkoitetun vehnän laatutukimuksien (LALLUKKA 1971) yhteydessä myös kenttäkoeaineiston satonäytteiden itävyydet. Määritysten perusteella tarkastellaan seuraavassa korjuuajankohdan ja -menetelmän vaikutusta vehnälajikkeiden itävyyteen. Vuoden 1966 määrityksistä laskettiin myös kylvösiemenen itämisnopeus, siis itämisajan puolivälissä laskettujen itujen osuus \%:ina. Itävyydet määritettiin vuosina 1966 ja 1967 2-3 viikkoa puinnin ja kuivatuksen jälkeen ja toisen kerran keväällä maalis-huhtikuussa. Tulosten avulla voitiin siten tehdä eräitä havaintoja koejäsenten itämiskypsymättömyydestä niinä vuosina. Vuonna 1968 itävyydet määritettiin vain yhden kerran, helmikuussa.

\section{Kenttäkokeiden järjestely}

Kokeet järjestettiin lohkottain satunnaistettujen ruutujen menetelmällä. Koejäsenet olivat:

Lajikkeet:

Korjuuajat:

Apu, Norröna, Timantti, Touko ja Svenno.

Korjuumenetelmät: leikkuupuinti (A)

lyhteiden kuivatus kuivurissa + puinti (B)

lyhteiden jälkituleentuminen suojattuna + puinti $(\mathrm{C})$

lyhteiden jälkituleentuminen ulkona seipäillä + puinti (D).

\section{Koevuosien sää}

Koevuosien sääoloja (taulukko 1) verrattaessa voitiin todeta, että kasvukautena 1968 olivat viljojen tuleentumisajankohtana vallinneet lämpö- ja kosteusolot suotuisimmat laadullisesti hyvän viljan tuottamiseen. Lämpötilat olivat korkeat ja sademäärät normaalia vähäisemmät. Vuonna 1966 oli kasvukauden alkupuoli, kesä-heinäkuu, hyvin lämmin ja kuiva, mutta sen sijaan elo- ja syyskuun lämpötilat olivat muiden koevuosien vastaavia keskilämpötiloja alhaisemmat. Vuonna 1967 kasvukausi alkoi viileänä, mutta viljojen tuleentumiskausi, elokuu ja syyskuun alkupuoli oli suhteellisen lämmin.

\section{Tulokset}

Koejäsenten itävyydet molempina määrityskertoina on esitetty kuvassa 1 ja itämisnopeudet vuonna 1966 kuvassa 2 . Kuvaan 1 on myös merkitty sakolukuarvojen vaihtelut murtoviivana.

Korju uajan ja - menetelmän va i kutus. Tuloksia tarkasteltaessa havaitaan, että edellä mainittujen tekijöiden vaikutukset olivat toisiinsa kytkeytyneitä. Korjuumenetelmän vaikutus etenkin varhaisessa korjuussa riippui suurelta osin siitä, liittyikö menetelmään jälkituleentuminen tai ei. Sen vuoksi laskettiin kunkin lajikkeen itävyys eri korjuuaikoina erikseen käytettäessä menetelmiä, joihin ei liittynyt jälkituleentumista ja joihin se liittyi. Itävyydet laskettiin koevuosien itävyyksien keskiarvoina ja ne on esitetty taulukossa 2 . 


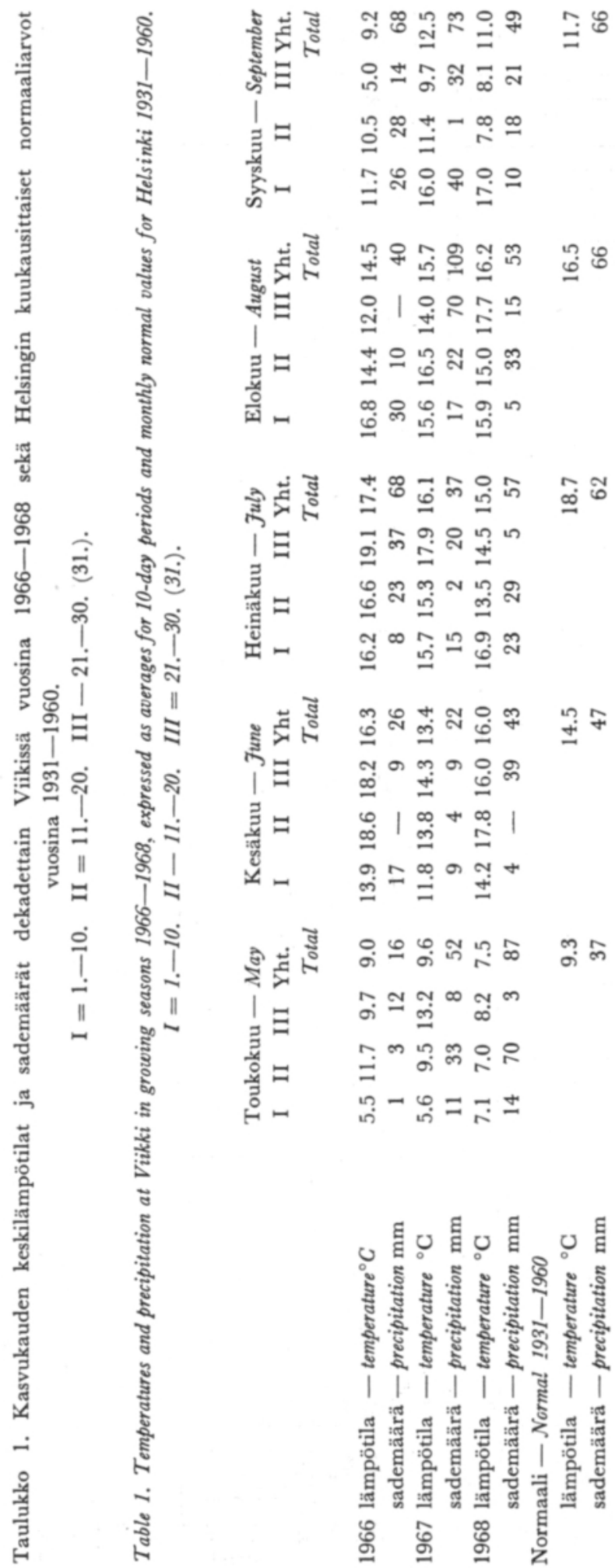



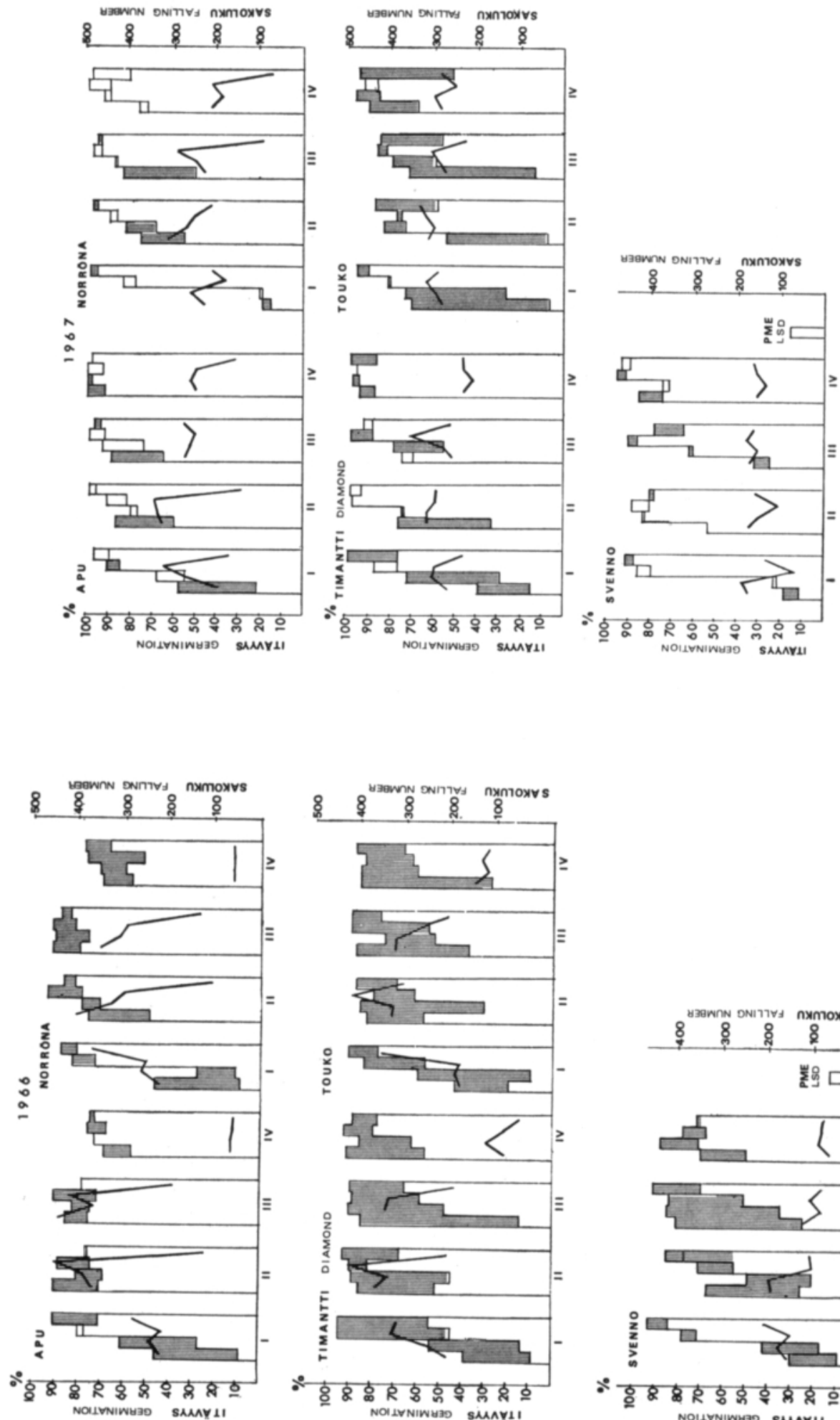

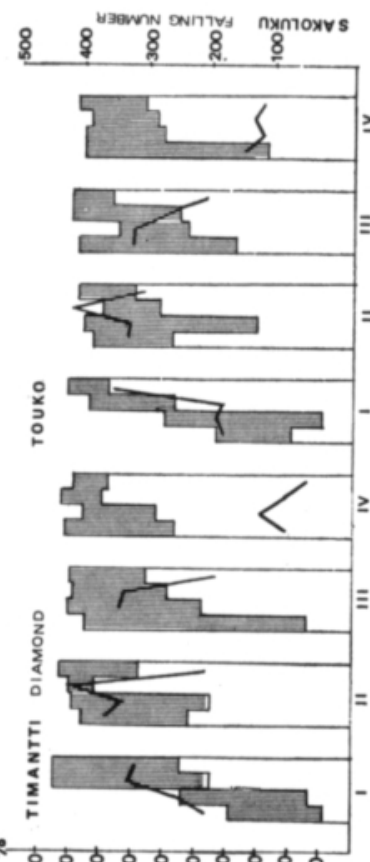

Nollyniwat

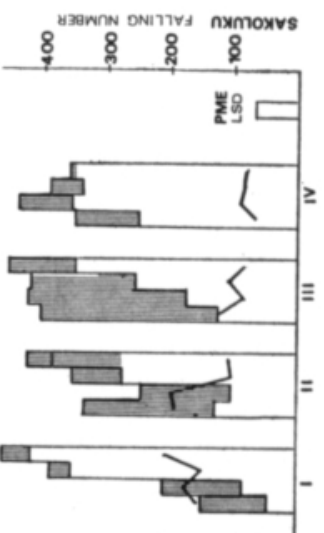

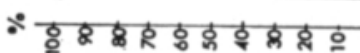
NOIIVNIwaso suayil 

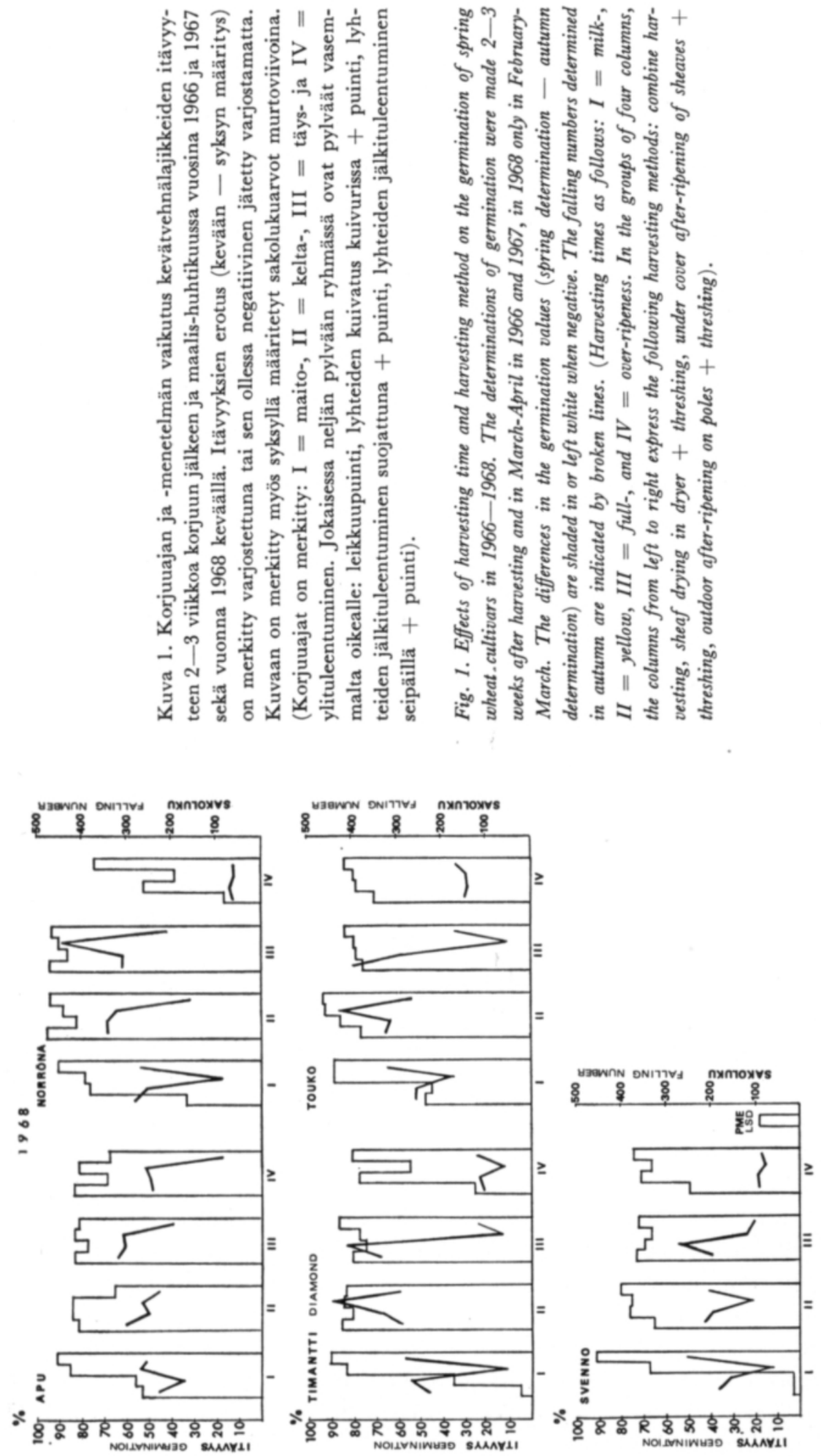


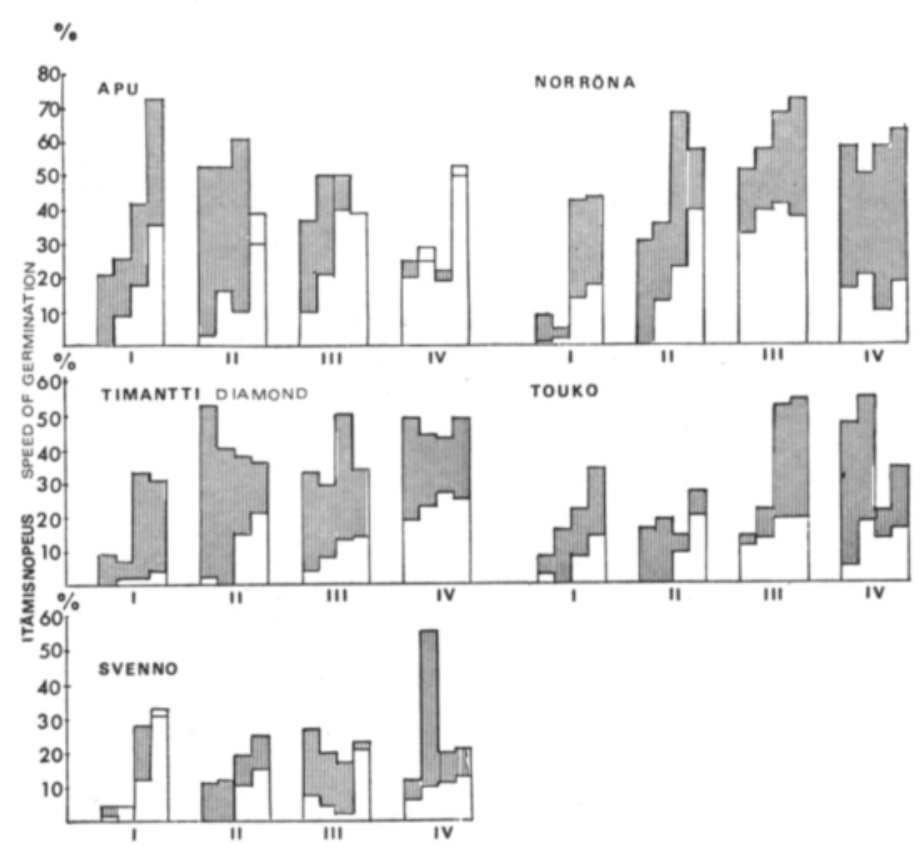

Kuva 2. Korjuuajan ja -menetelmän vaikutus kevätvehnälajikkeiden itämisnopeuteen $2-3$ viikkoa korjuun jälkeen ja maalis-huhtikuussa vuonna 1966. Itämisnopeuksien erotus (kevään — syksyn määritys) on merkitty varjostettuna tai sen ollessa negatiivinen jätetty varjostamatta. Korjuuajat ja menetelmät esitetty samoin kuin kuvassa 1.

Fig. 2. Effects of harvesting time and harvesting method upon the speed of germination of spring wheat cultivars in 1966. Speed of germination is determined 2-3 weeks after harvesting and in March-April. The differences in the two determinations (spring determination - autumn determination) is shaded in or left white when negative. Harvesting times and methods are same as in Fig. 1 .

Kun vehnä korjattiin menetelmin (A ja B), joihin ei liittynyt jälkituleentumista, heikensi maitotuleentumisasteella suoritettu korjuu voimakkaasti sadon itävyyttä. Jyvät rikkoutuivat leikkuupuitaessa (A), mikä aiheutti itävyyden menetystä. Puinnista johtuvia vaurioita havaittiin melko runsaasti myös vaillinaisesti itäneissä siemenissä. Lajikkeiden leikkuupuintikosteudet maitotuleentumisasteella vaihtelivat muutaman $\%$-yksikön verran eri vuosina. Keskimäärin ne olivat: Apu 40.6, Norröna 41.6, Timantti 41.5, Touko 41.1 ja Svenno $45.2 \%$. Niin kosteata viljaa käsiteltäessä ei myöskään kuivatusvaurioita voitu täysin välttää.

Menetelmässä B korjuu suoritettiin siten, että ensin kuivatettiin viljalyhteet lämminilmakuivurissa ja sen jälkeen ne puitiin. Nopeasti kuivatettaessa haurastuivat varhaisessa tuleentumisvaiheessa korjatut jyvät ilmeisesti, sillä puitaessa niitä rikkoutui melko runsaasti. Kuivatusvaurioitakin havaittiin jonkin verran. Menetelmällä B saatiin maitotuleentumisasteisena korjattaessa itävyydeltään hiukan parempaa viljaa kuin leikkuupuitaessa, mutta kumpaakaan menetelmää käytettäessä ei varhain korjattu sato täyttänyt itävyydeltään läheskään siemenviljan vähimmäisvaatimuksia. 
Taulukko 2. Korjuuajan vaikutus kevätvehnälajikkeiden itävyyteen erilaisia korjuumenetelmiä käytettäessä. Itävyysprosentit on esitetty $95 \%$ :n luotettavuusrajoineen koevuosien keskiarvoina.

Table 2. Effect of harvesting time upon the germination of spring wheat cultivars harvested by various methods. The germination is expressed as percentages with $95 \%$ confidence limits. The numbers are averages for the experimental years.

$\begin{array}{ll}\text { Lajike } & \text { Korjuuaika } \\ \text { Cultivar } & \text { Harvesting time } \\ & \text { tuleentumisvaihe } \\ & \text { korjattaessa } \\ & \text { ripening stage } \\ & \text { at harvesting }\end{array}$

Korjuumenetelmä

Harvesting method

ei jälkituleentuneet

not after-ripened jälkituleentuneet

after-ripened

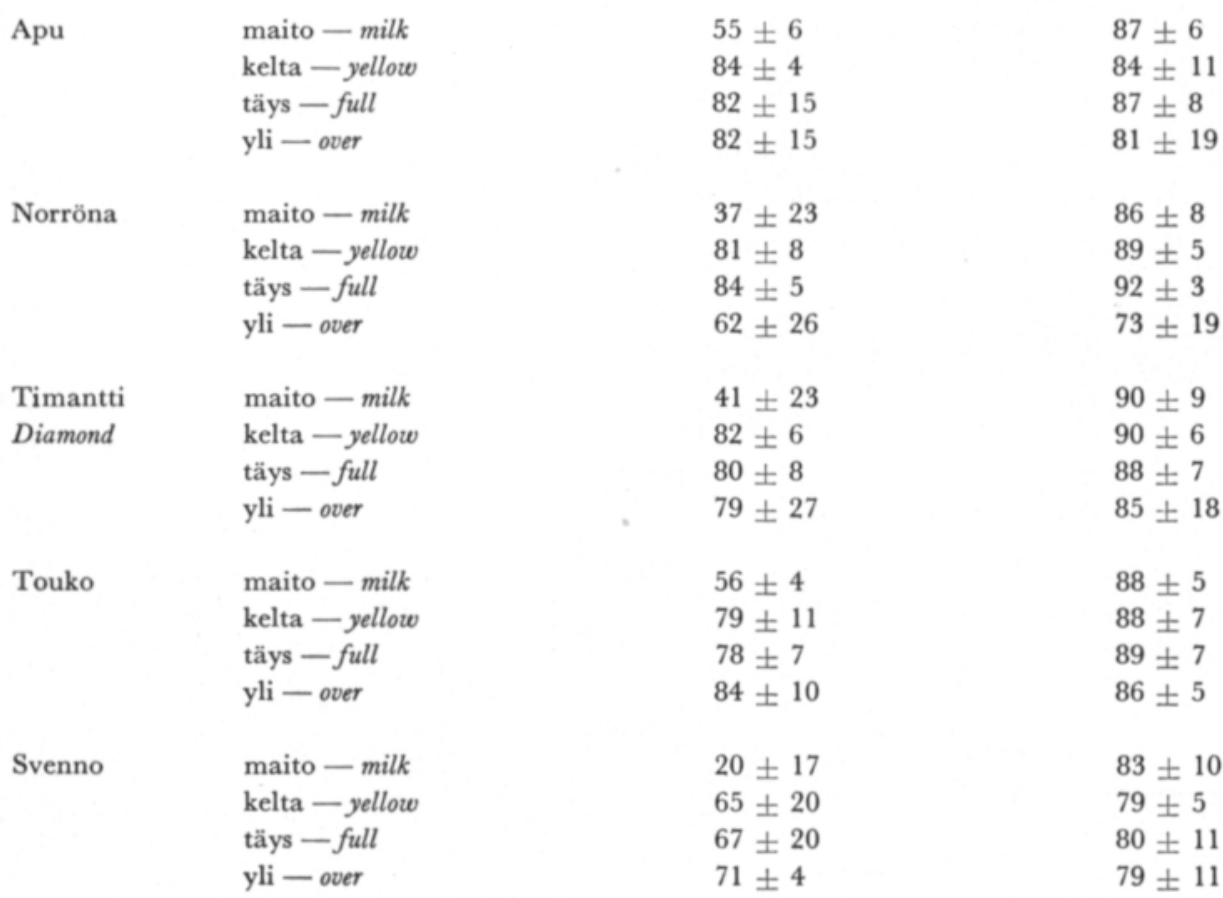

Kun maitotuleentuneena leikatun vehnän annettiin ennen puintia jälkituleentua hitaasti joko suojattuna (menetelmä C) tai ulkona seipäillä (menetelmä D), saatiin yleensä itävyydeltään siemenviljaksi kelpaava sato.

Suoritettaessa korjuu kelta- tai täystuleentumisasteella (tässä tutkimuksessa oli kysymyksessä keltatuleentumisen jälkipuolisko, jolloin hyvän kosteudet olivat: Apu 24.8, Norröna 25.9, Timantti 26.8, Touko 25.5 ja Svenno $29.8 \%$ ) saatiin kaikilla tutkituilla menetelmillä yleensä tyydyttävästi tai hyvin itävää siemenviljaa.

Ylituleentuneessa vehnässä voitiin todeta itävyyden lievää heikentymistä useissa tapauksissa. Sakoluku oli silloin tavallisesti voimakkaasti alentunut (kuva 1). Sen huomattava heikentyminen ei kuitenkaan aina välittömästi merkinnyt itävyyden huonontumista. Kun ylituleentunut vilja leikkuupuitiin, itävyys näytti yleensä jäävän pienemmäksi kuin 
muilla menetelmillä korjattaessa. Tämä ilmeisesti johtui siitä, että ylituleentuneen viljan kosteus saattoi olla suurehko leikkuupuitaessa, kun taas muihin menetelmiin liittyvissä käsittelyissä jyvät kuivahtivat ennen puintia.

L a j i k k e e n va i u t u s. Maito-, kelta- ja täystuleentuneena leikatussa ja vasta jälkituleentumisen jälkeen puidussa vehnässä lajikkeiden itävyyksien väliset erot olivat kohtalaisen vähäiset. Svennon itävyydet näyttivät olleen jonkin verran alhaisemmat kuin muiden tutkittujen lajikkeiden. Lajikkeiden väliset erot olivat hieman selvemmät menetelmissä, joihin ei liittynyt jälkituleentumista. Svenno- ja Norröna näyttivät kestäneen heikommin kuin muut tutkitut lajikkeet aikaisella tuleentumisasteella suoritettua puintia, jolloin jyvän kosteus oli vielä suuri ja jyvä oli pehmeä. Vastaavanlaiseen tulokseen on päädytty Lounais-Suomen koeasemalla suoritetuissa tutkimuksissa (KöYLIJÄRvi 1970). Tässä yhteydessä on kuitenkin todettava, että Svennolla oli sekä maito- että keltatuleentumisasteella puitaessa jyvän kosteus hieman suurempi kuin muilla lajikkeilla ja se osaltaan todennäköisesti vaikutti jonkin verran itävyystuloksiin.

I t ä m i s k y p s y mä t t ö m y y s. Tässä kirjoituksessa itämiskypsymättömyyttä tarkastellaan vertaamalla syksyllä $2-3$ viikkoa puinnin jälkeen määritettyä itävyyttä keväällä määritettyyn itävyyteen (kuva 1). Itämiskypsymättömyys näytti riippuvan korjuuajasta, -menetelmästä, lajikkeesta ja koevuodesta.

Itävyyden muuttuminen oli suurin koejäsenissä, jotka oli korjattu varhaisessa (kelta-) tuleentumisvaiheessa eikä korjuumenetelmiin liittynyt jälkituleentumista. Maitotuleentumisvaiheessa ilman jälkituleentumista korjatuissa koejäsenissä itävyys heikkeni puintivaurioiden seurauksena eikä itävyyden kohoamista kevääseen mennessä sen vuoksi voinut tapahtua. Itämisnopeuksissa tapahtuneet muutokset olivat hyvin samansuuntaiset, kuitenkin suhteellisesti ehkä vielä hieman suuremmat kuin itävyysmääritysten erot.

Svennon itämiskypsymättömien jyvien osuus oli runsaampi kuin Apu- ja Norrönavehnien, mutta selvästi vähäisempi kuin Touko- ja Timantti-vehnien, kuten alla oleva osoittaa.

$\begin{array}{lccc}\text { lajike } & \text { kevään ja syksyn itävyyksien erotus \%-yksikköinä } \\ & 1966 & 1967 & \text { keskim. } \\ \text { Apu } & 12 & 3 & 8 \\ \text { Norröna } & 14 & 2 & 8 \\ \text { Timantti } & 32 & 10 & 21 \\ \text { Touko } & 30 & 23 & 27 \\ \text { Svenno } & 23 & 12 & 18\end{array}$

Vuonna 1966 oli itävyyksien kohoaminen kevääseen mennessä suurempi kuin vuonna 1967. BELdERokin $(1965,1968)$ mukaan lämmin sää jyvän kehitysvaiheessa (lähinnä maito- ja keltatuleentumisen välillä) lyhentää itämislepoa. Kukin viljalaji ja -lajike tarvitsevat täyden itämiskypsyyden saavuttamiseksi lämpömäärän, joka voidaan todeta tietyllä tavalla lasketusta lämpötilasummasta maito- ja keltatuleentumisen välillä.

Vuonna 1966 jyvien alkukehitys (heinäkuu - elokuun ensimmäinen kolmannes) tapahtui huomattavasti lämpimämmissä olosuhteissa kuin vuonna 1967. Sen sijaan elokuun 10. päivän jälkeen vuosi 1966 oli keskilämpötiloiltaan seuraavaa vuotta melkoisesti viileämpi (taulukko 1). Tutkituista lajikkeista varhaisimman, Apu-vehnän, ensimmäinen 
puinti suoritettiin vuonna 1966 elokuun 9. p:nä. Apu oli silloin maitotuleentunutta. Kaikkien tutkimuksessa mukana olleiden lajikkeiden maito- keltatuleentumisen välisen ajan lämpötila oli siis vuonna 1966 alhaisempi kuin vuonna 1967. Se selittänee osittain vuoden 1966 kokeessa havaitun jyvien suuremman itämiskypsymättömyyden vuoden 1967 kokeeseen verrattuna. Tosin vuoden 1966 alkukesän kuivuudesta johtunut melko runsas jälkiversonta saattoi myös osaltaan suurentaa itämislevossa olevien siementen määrää kuvaavia prosenttilukuja. Siihen viittaavat melko korkeat itämiskypsymättömyysprosentit vielä eräissä täys- ja ylituleentuneissakin koejäsenissä. Myöhäisissä tuleentumisvaiheissa korjatussa sadossa esiintyneiden jälkiversojen jyvät olivat ehkä olleet maito-keltatuleenneita ja siis oletettavasti itämiskypsymättömämpiä kuin pääosa sadosta.

Hieman ristiriitaiselta vuoden 1966 suurien itämiskypsymättömyyslukujen kanssa näytti sakolukujen voimakas aleneminen ylituleentumisen aikana sinä vuonna. Vuonna 1967, jolloin itämiskypsymättömyys Viikissä suoritetuissa kokeissa oli pienempi, sakoluvut säilyivät pitempään korkeina. Sakolukujen erilaiseen alenemiseen vaikuttivat luonnollisesti myös ylituleentumiskauden säät. Vuonna 1966 esiintyi Viikissä kokeen ylituleentumisen aikana keskimäärin runsaammin sellaisia ajanjaksoja, jolloin tähkäidäntä Pessin (1965) mukaan on mahdollista, kuin vuonna 1967 (vrt. LALlukKa 1971).

\section{Tulosten tarkastelua}

BELDERoKin (1965) mukaan itämislepo voidaan jakaa kahteen jaksoon

1) välittömästi korjuuta seuraavaan vaiheeseen, jolloin itävyysprosentti on hyvin alhainen, 2) jälkituleentumista seuraavaan siirtymävaiheeseen, jossa itämislepo vähitellen heikkenee.

Kylvösiemenarvoa tarkasteltaessa lienee toisella vaiheella merkitystä. Sen sijaan ensimmäisen vaiheen syvyys ja kesto kuvastanevat lähinnä viljan tähkäidäntäherkkyyttä.

Tässä kirjoituksessa tarkastellut itämiskypsymättömyyttä kuvaavat prosenttiluvut vastannevat lähinnä toista vaihetta. Ilmeistä kuitenkin on, ettei ensimmäinen jaksokaan vielä ollut kokonaan päättynyt kaikissa tapauksissa. On mahdollista, että tähkäidäntää kestävillä lajikkeilla itämislevon ensimmäinen vaihe on pitempi kuin tähkäidännälle alttiilla lajikkeilla. Tähän viittaavat esim. Touko- ja Timantti-vehnillä ensimmäisissä määrityksissä havaitut alhaisemmat itävyysprosentit kuin muilla tutkituilla lajikkeilla. Itämislevon ensimmäinen vaihe jatkui näillä lajikkeilla ehkä selvemmin kuin toisilla vielä $2-3$ viikon kuluttua sadon korjuusta. Lajikkeiden välisiä eroja voi luonnollisesti olla myös itämislevon toisen vaiheen syvyydessä ja kestossa. Kaiken kaikkiaan perinnöllisten erojen on havaittu vaikuttavan erittäin voimakkaasti itämislevon kestoon (NrLsson-Ehle 1914, Greer ja Hutchinson 1945, Lochow 1952).

Myös lajikkeen aikaisuudesta johtuvien tuleentumiskauden erilaisten sääolojen voidaan meidän ilmastossamme ajatella vaikuttavan perinnöllisten ominaisuuksien ohella lajikkeiden välisiin itämislevon kestossa esiintyviin eroihin. Useina vuosina saavuttavat aikaiset lajikkeet todennäköisesti varmemmin maito - keltatuleentumisensa aikana itämiskypsyyteen tarvitsemansa lämpötilasumman kuin myöhäiset lajikkeet.

Esitettyjen tulosten perusteella ei voida päätellä, olisiko itämisestoisuus koejäsenistä hävinnyt jo paljon aikaisemmin kuin helmi-maaliskuussa (jolloin toinen itävyyden määrittäminen suoritettiin) ja olisivatko itävyysarvot ehkä vielä jonkin verran kohonneet kylvöaikaan mennessä tai sen jälkeen. HrLlın (1963) tutkimuksissa todettiin keväällä 
suoritetuissa idätyksissä itämiskypsymättömiä siemeniä olevan enää $4 \%$. Mainitut tutkimukset tehtiin vuonna 1962, jolloin itämiskypsymättömyys oli syksyllä erittäin suuri kaikissa viljoissa. Voitaneenkin päätellä, että jos jyvien itämättömyys syksyllä johtui niiden itämiskypsymättömyydestä, ei se seuraavan kevään kylvöjä ajatellen ollut haitallista. Itämiskypsymättömyys nimittäin hävisi kevääseen mennessä, niin että vilja saavutti tyydyttävältä tai hyvältä kylvösiemeneltä vaadittavan itävyyden. Kylvösiemenen varmuusvarastoinnin kysymyksessä ollen voi kuitenkin liian varhain suoritettu korjuu ja sen seurauksena esiintyvä suuri itämiskypsymättömyys osoittautua haitalliseksi (vrt. Suomela 1969). Itämiskypsymätön siemen saattaa nimittäin menettää itävyytensä herkemmin kuin kehitysaikanaan täysin itämään kypsynyt siemen.

Korjuun viivästyessä näytti Norröna-vehnän itävyys alentuneen selvemmin kuin muiden tutkimuksessa mukana olleiden lajikkeiden. Tutkituista lajikkeista Norröna tunnetaan myös herkimmin tähkissä itäväksi (esim. Manner 1968, Suomela 1969, LallukKa 1971). Norrönan itävyyden selvä alentuminen saattoi osittain johtua siitä, että Norrönassa oli tähkäidäntä edistynyt pitemmälle kuin muilla lajikkeilla. Voi myös olla niin, että tähkäidännän edistyessä sen itävyys heikkeni suhteellisesti herkemmin kuin muiden tutkittujen lajikkeiden.

\section{$P$ ä $\operatorname{tel} m \ddot{a} t$}

Tutkimuksessa havaittiin, että jos kevätvehnä korjattiin maito - täystuleentuneena menetelmin, joihin liittyi jälkituleentuminen ennen puintia, sato täytti itävyydeltään yleensä hyvälle kylvösiemenelle asetetut vaatimukset. Jos korjuu tapahtui menetelmin, joihin ei liittynyt jälkituleentumista, maitotuleentuneena korjatun viljan itävyys jäi erittäin alhaiseksi. Korjuun viivästyessä itävyys heikkeni yleensä jonkin verran.

Tutkituista lajikkeista Norröna ja Svenno näyttivät kestäneen heikoimmin varhaisella tuleentumisasteella suoritettua puintia. Ylituleentuneena korjattaessa Norrönan itävyys heikkeni voimakkaimmin.

Jyvien itämiskypsymättömyys $2-3$ viikkoa korjuun jälkeen näytti olevan varhain korjatuissa koejäsenissä suurempi kuin täys- tai ylituleentuneina korjatuissa, etenkin jos korjuumenetelmään ei liittynyt jälkituleentumista. Itämiskypsymättömyys oli suurempi tähkäidäntää kestävillä kuin sille alttiilla lajikkeilla.

Jyvien itämiskypsymättömyyteen näyttivät vaikuttavan myös tuleentumista edeltävän ajan sääolot.

Itämiskypsymättömyys väheni kylvöaikaan mennessä niin, että vehnän itävyys silloin täytti kylvösiemenelle asetetut vaatimukset.

\section{KIRJALLISUUTTA}

Belderok, B. 1965. Einfluss der Witterung vor der Ernte auf die Keimruhedauer und die Auswuchsneigung des Weizens. Z. Acker- und Pfl.bau 122: 297-313.

- - 1968. Seed dormancy problems in cereals. Field Crop Abstr. 21:203-211.

GreER, E. N., \& Hutchinson, J. B. 1945. Dormancy in British-grown wheat. Nature 155: 381.

HrıLı, A. 1963. Itämiskypsymättömyyden esiintymisestä viljoissa. Koetoim. ja Käyt. 20: 24.

KöYLIJÄRVI, J. 1968. Aikaisen leikkuupuinnin merkitys leipäviljan tuotannossa. Ibid. 25: 27.

$\longrightarrow »$ 1970. Puintikosteuden vaikutus itävyyteen. Ibid. 27: 25, 28. 
LALluKKA, U. 1971. Eräiden ulkoisten tekijöiden ja kasvien morfologisten ja fysiologisten ominaisuuksien vaikutus kevätvehnän tähkäidäntään. Acta Agr. Fenn. 121: 1-100.

Locноw, J. von 1952. Sprouting resistance in wheat. Agri Hort. Gen. 10: 113-140.

MANNER, R. 1968. Kevätvehnälajikkeiden sakoluvuissa esiintyy huomattavia eroja. Koetoim. ja Käyt. 25: 25, 27.

Neuvonen, V. 1966. Tutkimus leikkuupuinnin ajankohdasta ja vaikutuksesta itävyyteen ja sakolukuun. Koneviesti 14, 16: 2-3.

Nilsson-Ehle, H. 1914. Contribution to knowledge of the internal factors associated with germination physiology of wheat. Z. Pfl.zücht. 2: 153-187.

Pessi, Y. 1965. Some features in Finnish climate affecting cereal harvesting. Maatal.tiet. Aikak. 37: 98-103.

SuomelA, H. 1969. Eräiden kevätvehnälajikkeiden tähkäidännän kestävyys valtion viljavaraston sopimusviljelyksillä vuosina 1966-1967. Ann. Agric. Fenn. 8: 244-250.

VAlle, O. 1954. Kevätvehnän leikkuupuinnista korjuukautena 1954. Koetoim. ja Käyt. 11: $37,40$. 